\title{
A Reflection on an Emergent Spirituality and the Practice of Adult Education
}

\author{
Allan C. Lauzon, University of Guelph
}

\begin{abstract}
The idea of spirituality is increasingly being used in the context of adult education. This paper will tentatively explore some of the implications of an emergent spirituality within the practice of adult education. It begins by situating our understanding of spirituality in an historical context. This is followed by a brief historical overview of the relationship between spirituality, social change, and the practice of adult education. Building on this brief historical analysis, our understanding of an emergent spirituality is argued to be a property of the evolution of human consciousness. The implications of an emergent spirituality for the practice of adult education are then examined.
\end{abstract}




\section{INTRODUCTION}

In the context of modernity, spirituality and religion have often been used synonymously. To be spiritual was to be religious and to be religious was to be spiritual. Yet we now have a different understanding of spirituality and why one can be both religious and spiritual: to be religious is not necessarily to be spiritual and to be spiritual is not necessarily to be religious. In fact, much of contemporary spirituality draws on many religious traditions and on an ecumenical belief that spiritual truth can be known and articulated in a variety of different ways. I believe what I have termed "an emergent spirituality" is a response to the alienation and anomie we have experienced as a consequence of modernity.

Thus contemporary spirituality is grounded in an attempt to make sense of the world, to create meaning, in order to escape our alienated condition. Benjamin and Looby (1998) pointed to this search for meaning when they quoted Myers, who said that spirituality is a "continuing search for meaning and purpose in life; an appreciation for the depth of life, the expanse of the universe, and natural forces which operate; a personal belief system" (p. 92). They added that spirituality requires a striving for a "balance between their inner and outer selves" (p. 92). English (2003) described this form of spirituality as a public spirituality that

is worked out in the everyday world of human existence. . . This is a spirituality of living and being, which is broad enough to be inclusive of all practices and beliefs; its focus is on the living of relationship and the development of meaning-making as adults. (p. 2)

Contemporary spirituality is not something simply to be learned about-it is experiential; we know the creation and we make meaning by engaging the creation. For many, the first glimpse into this world is through peak experiences, those moments that Maslow (1964) described as an experiential reckoning whereby we acknowledge and feel in a very concrete and real way that we are simply part of the whole; the creation is one and we are part of that oneness. He further described this experience as being characterized by a "non-evaluating, non-judging, or non-comparing cognition" (p. 60). For me, Charlene Spretnak (1991) captured the essence of this emergent spirituality when she argued that we are inextricably linked at the molecular level to every other level of the great unfolding. We are the descendants of the fireball, the pilgrims of the earth glimpsing the oneness of the sacred whole, and in glimpsing the oneness we come to know Gaia and grace. When we experience our connection with others and the larger universe, recognizing that we are part of the whole, there is nothing left to compare, judge, or evaluate, for the "we" is really an "I." 
Lauzon (1998a) has argued that we are living through a fundamental evolutionary transformation of human consciousness, characterized by a new and emergent means of "knowing" that transcends a simple, rational logic; in other words, it is a new emergent epistemology. This epistemology is then reflected and institutionalized according to how we organize socially and the modes of production we engage in. Furthermore, spirituality is an emergent property of this evolutionary transformation of consciousness, which will challenge our understanding of the adult learner and have implications for the practice of adult education. Clearly, numerous writers in adult education have undertaken this challenge, and as English (2005a) made clear, there is a growing body of literature on spirituality, adult education, and adult learning. Moreover, the contemporary literature focuses a great deal on the relationship between spirituality and social justice. Tisdell's (2000) study is exemplary of this form of research, exploring the role of spirituality in the life of adult educators who are actively engaged in education for social change. Yet as English (2005b) reminded us, spirituality and social change were integral to the Canadian practice of adult education in its early years and "spirituality can be linked in many ways to the field's roots and initial purposes" (p. 1173).

In this article, the goal is to begin to reflect on the implications of an emergent spirituality for the practice of adult education. A short historical overview of spirituality, social change, and adult education is offered first, followed by a brief section in which the argument is made that we are engaged in a fundamental shift characterized by the evolution of consciousness, a shift that is accompanied by and incorporates an emergent spirituality. The article ends with reflections on the implications for a spiritually inspired pedagogy for adult education and some tentative conclusions.

\section{Spirituality, Social Change, and Adult Education: A Short Historical Overview}

Adult education as a field of practice has a long and well-established history and tradition of working for social justice in the Canadian context. Prior to World War II, Canadian adult education drew much of its philosophical inspiration from the social democracy and social gospel movements, which resulted in such programs and institutions as the Antigonish movement, Frontier College, and the Farm Radio Forum. Gordon Hawkins, a former associate director of the Canadian Association for Adult Education, wrote that Canadian adult education

stems from a deep concern with the processes of democracy-with how the individual and the group and the community work, as much as with what they set out to achieve. Hence the emphasis in their scheme 
of things, on group work, community organization, discussion methods and techniques, leadership courses and so on ... (cited in Selman \& Dampier, 1991, p. 46)

Father Jimmy Thompkins of the Antigonish movement (cited in Welton, 2001) captured the essence of early Canadian adult education when he stated:

Our experience in the Antigonish Movement is that there is more real Adult Education at the pit heads, down in the mines, out among the fishermen's shacks, along the wharves, and wherever farmers gather to sit and talk in the evenings, than you can get from one hundred thousand dollars' worth of fossilized formal courses. It springs from the heart and pains of people. (p. 115)

And although adult educators did not deal with spirituality as we currently understand it, their pedagogy and practice were spiritually inspired in a vision of democracy and social justice as they actively reached out to those on the margins of Canadian society.

The onset of World War II marked a turning point in adult education in Canada and elsewhere. Subsequent to the war, in the 1950s and into the early 1960s, adult education was professionalized, with an increased emphasis on adult educators acquiring the necessary technical skills but with little consideration as to how those skills would be used. In many ways, adult education during this period was separated from its historical social mission and replaced by an ethos that was dominated by the psychology of learning and the adult learner. Furthermore, in an attempt to legitimize their "professional" existence, adult educators argued that practice must be based upon an empirical research base grounded in a positivist epistemology.

It was by attempting to become scientific that adult educators attempted to legitimize the profession and their expertise at the expense of the historical social mission of Canadian adult education. Practice was to be guided by science, and adult educators were to become "experts" with knowledge in the science of teaching adults. Increasingly, the focus became the individual and individual change, with a particular emphasis on education, employment, and the economy or, in other words, human capital formation. Spirituality and spiritually inspired education were increasingly marginalized as the separation between state and church began in earnest under the auspices of professionalization and led to the secularization of Canadian adult education. Consequently, spirituality was then only addressed in the context of religious education (English, 2005b). 
Although these changes continued to influence the field and practice of adult education, the rise of the feminist movement, the anti-war movement, and the civil rights movement in the 1960s and beyond began to challenge and undermine the dominant discourse of modernity, creating space for competing discourses (Hobsbawn, 1995). The world of professional adult education was not left untouched as competing educational discourses began to emerge. In particular, the work of Brazilian educator Paulo Freire and the publication of his book The Pedagogy of the Oppressed (1970) began to shift the practice of adult education and provided the foundations for the rise in the 1980s of critical pedagogy, a pedagogy that once again embodied a belief that adult education could be a vehicle for social transformation, especially for those who exist on the margins of society. Increasingly, these changes served as a challenge to the dominant orthodoxy of adult education and laid the groundwork for spirituality to be reclaimed by adult educators.

Spirituality as it emerged in the 1990s, however, was rooted in the individual's direct experience of both the material world and the divine and the meaning ascribed by the individual to both. Thus an emergent spirituality, like adult education, began with the idea that such a spirituality required learners to engage their experience and to name it for themselves (Lauzon, 2003). This perspective very much parallels the political views of Freire, who worked with peasants and the marginalized in Brazil and Africa, assisting them to name their world for themselves and to act upon that world in order to change it. In doing so, they could escape their oppression and work toward creating a more just world. In this sense, the emergent spirituality we see in the adult education literature is inextricably bound to the tradition of adult education for social transformation and justice. Clearly, Freire's work, which drew from both Marxism and liberation theology and which tied the spiritual life to political liberation, has found expression in the contemporary literature in adult education. For example, Tisdell (2000), in interviews with adult educators who self identified as being spiritual and having a spiritually inspired practice, reported that they "saw their spirituality and their social justice efforts as an integrated way of life and as a way of thinking and being in the world" (p. 328).

Thus, for many adult educators, spirituality and work for social justice are inextricably intertwined and cannot be separated. It is as English (2005b) suggested, I believe, that spirit and social change are integral to one another. The difference between the current period of adult education and preWorld War II adult education is that prior to the war spirituality and religion informed the social mission of adult education, often embodied in the Good 
News, while now spirituality is not only a means of informing the mission of adult education but is part and parcel of identity, the learning process, and knowledge construction, which is the basis for social transformation. The origins of today's spirituality are not doctrine but are constructed out of the individual's and the collective's experience. Thus spirituality is not just about relationships to others and the larger environment but is about identity and knowledge construction; it begins to heal the modern split between the individual and the social and this informs the practice of adult education. English (2005b) suggested this when she wrote:

The acceptance of the twin purposes for adult education, spirituality and social change, affects epistemology in our field, what it means to know and how one goes about knowing; how it affects practice, what it means to practice, and to go about practicing; how it affects morality, what it means to reclaim a focus on a social change mandate rooted in axiological categories such as moral value, beauty and worth. (p. 1187)

English concluded that spirituality and social change "will move adult educators closer to reconciling the personal and collective divide in our field, regardless of whether we are concerned with personal, workplace, basic education or social needs or with the moral value, beauty, and worth of adult education" (p. 1187). We are learning to move beyond the parts and embrace the whole.

In the next section I examine these changes, arguing that they constitute a fundamental shift in the ongoing evolution of human consciousness. Bussey (2002) described this evolution of consciousness as a critical spirituality, a spirituality that is characterized by the "collective struggle to achieve ever higher order spaces in which subtlety and spirit can emerge, through conscious human engagement, into the collective domain" (p. 306).

\section{Spirituality as an Emergent Property of HuMAN CONSCIOUSNESS}

It has become almost cliché to talk of "changing times." Yet, as I noted earlier, I believe we are engaged in a fundamental shift in human consciousness, which is expressed in how we make sense of the world (epistemology), how we organize socially, and what it means to be human, including the emergence of a new understanding of spirituality (Lauzon, 1998a; 1998b). In an earlier work, inspired by the work of Gregory Bateson (1979) and his desire to seek the pattern that connects, I strived to identify patterns that connect themes across emergent theological writing to determine if there was a common pattern to shifts in messages emanating from what appear to be dispa- 
rate theological perspectives. Specifically, I examined liberation theology, creation theology, and woman-centred theology. Out of this review I identified five common themes (Lauzon, 1995).

First, in the words of eco-theologian Thomas Berry (1988), all three literatures talked about the need for a "new story." The emergent spirituality that I refer to in this article is part of that new story.

Second, this new story and its emergent spirituality are grounded in personal experience and not doctrine; the new story constitutes the spiritualization of experience, and spirituality is experienced rather than learned about. Reason (1998) highlighted this in his articulation of a participatory world view, a world view he would argue, and I would concur, that is emerging as a result of the many challenges and changes we are collectively facing (environmental destruction, increasing poverty, etc.), a world view that is inherently spiritual in nature.

Third, all three perspectives described the need for healing. Modernity, with its fragmented world view, has left us in a disassociated state (Wilbur, 1995) whereby we are estranged from the larger environment, others, and ourselves (Lauzon, 1995).

Fourth, there is a need for liberation, particularly for those who are, in the words of Freire, oppressed. Liberation is part of the process of healing whereby individuals and collectives come to name the world for themselves, based upon their experiences and the meaning attributed to those experiences.

Fifth, dialogue is an instrumental process to constructing a common reality that leads to social and political action and a shared spirituality. This is not to negate differences but it does acknowledge and provide a space for identifying and / or constructing commonalities.

Collectively, these five themes constitute a fundamental shift from a linear logical model of knowledge, premised on formal operations, to a meta-logic that can acknowledge, account for, and integrate competing logics in a particular historical moment and spatial context. It is based cognitively upon post-formal operations and a dialectical logic (Lauzon, 1998a) and is known as vision-logic (Wilbur, 1995; Lauzon, 1998a). Furthermore, there is a corresponding shift in social organization, with movement from hierarchical social organization that is characterized by bureaucracies toward more fluid, networked forms of social organization (Castells, 2000). From a religious perspective, this leads toward a more ecumenical approach to organized spirituality-otherwise known as religion-whereby other traditions are acknowledged as legitimate and complementary and, on the level of the individual, there is an acknowledgement of the experiential basis of spiritual life. Thus spiritual life is not embedded within hierarchal and patriarchal institutions of religion and prescribed rules for living life but rather in the fabric of the 
everyday life of individuals as they strive to make meaning out of their experience. This is the essence of what English (2003), drawing on the work of Thomas Berry (1988), has called a "public spirituality."

I now turn to the implications for adult education.

\section{A Spiritually InSPIRed Adult EducAtion}

After World War II, adult educators essentially ignored spirituality as a dimension of human life, human learning, and education. However, in the last 10 to 15 years there has been a renewed interest in spirituality and the role it plays in the learning of both children and adults. In this section, a conceptualization of a spiritually inspired pedagogy for the practice of adult education is outlined.

Let me begin by stating that there is nothing definitive that can be said about addressing spirituality in the context of adult education. Spirituality ebbs and flows in ways we do not fully comprehend. Needs, a foundational concept in the adult education field, are not necessarily definitive and arise in the space between the social world and the inner personal world. In other words, needs arise in the space between the objective and the subjective. Thus we must recognize that spirituality is not static nor is it a state; it is not a destiny but a journey. Our spirituality evolves and changes, as do our needs, in light of our experiences, our changing understanding of our experiences, and our changing relationship to self, others, and the larger environment. It is these relationships, I believe, that are central to spirituality and it is through these relationships that we experience what I would call the divine and what others may call a higher power. Thus central to spirituality within the context of education is relationship.

Given the above point, what then is the purpose of adult education? Although many laudable goals have been attributed to the field of adult education, including social change/transformation, personal development, and skill development for vocational reasons, the fundamental purpose of a spiritually inspired adult education is to develop an educational process that creates opportunities for the development of autonomy and choice. It is only in having choice that individuals can name the world for themselves, and it is in naming the world for themselves that learners create the conditions and opportunities to create meaning - which is at the very heart of a spiritually inspired adult education. Also, autonomy and choice are prerequisites for relationships of interdependence rather than dependence. It is only from a position of autonomy and independence that an individual can enter into an interdependent relationship.

Second, a spiritually inspired adult education must address the issue of oppression and focus its energy on social change through the transformation 
of structural power relationships. It is only in transforming oppressive structures that we create opportunities for people to engage the world on their own terms. However, this necessitates that we respect and accept diversity as a starting point, and there are many ways of viewing and knowing the world as we seek "truth." From a spiritual perspective, this is captured by Maher and Hunt (1993) who stated:

People may start life's trek at a variety of trail heads, climb at different paces, and confront terrain that is both inviting and discouraging. Yet as the peak draws near, the realization surfaces that everyone was headed in the same direction all along. (p. 27)

In others words, the human race is characterized by differences but we need to recognize the commonalities among us. This, from my perspective, addresses the spiritual dimension of life.

Commonality, or common understanding, however, is built through a process of dialogue whereby we move beyond difference and through conflict. A spiritually inspired education that recognizes and respects difference and attempts to build commonality across difference must be open to conflict. Thus conflict is not a sign of ill health but a sign of health. As we seek to build this commonality we need to engage in a variety of ways of knowing that respect difference and differences. Education, while often the domain of logos, should also create space for eros. We must strive to engage learners in their fullness, recognizing the importance of body, mind, feeling, and spirit as complementary ways of knowing the world and others. We must also come to embrace narrative and story as a way of articulating our truths, for it is through story that humans can identify with "other." We see in them a mirror that reflects back to us part of our own essence, our own experience, and provides a "connection" to begin to build a "bridge" across difference. We learn to understand their truth through our truth, as all human stories reflect some aspect of human existence that we can identify with. We must acknowledge that knowledge is not linear and abstract but textured and imbued with meaning from a variety of locations, all illuminating part of our reality. Through sharing our own truths-be they individual or collective / cultural-we come to a greater understanding of reality. Thus knowledge, by definition, is always constructed in context and is always local. And this returns us to the notion of relationship. All knowledge construction in this context arises through engagement that is characterized by intimate relationship_relationship with self, others, and the larger environment.

As an educator, I must strive to create spaces that are respectful and attentive to the needs of individuals, the collective, and the environment. I need 
to create opportunities to engage autobiography, for it is through engaging autobiography that we name our world and develop our agency. We share our stories and build a common understanding. As an educator, I must also embrace Freire's (1970) notion of learner-teacher and teacher-learner. We are all learners in this context. This is not to deny my power or responsibility in this context but rather to recognize that I can share and participate; I can participate with others in the construction of local knowledge despite my role and status as "teacher." This requires that I am not merely a facilitator but I engage others through taking risks and sharing my own stories. They too can contribute to our collective understanding if they are offered in the spirit of collective knowledge construction. As I share my stories I must also help create and support a dialogical space where others can share their stories and where the question of what does this mean can be posed. This means that I must strive to foster an ethic of care, for we are not only responsible for ourselves, we are responsible for and to others, to their learning and to their care. Much of what I do as a teacher is to provide support and encouragement, to help individuals and collectives reach deep within and find the courage to name the world for themselves rather than accept the names of others. My final responsibility as a teacher in this process is to bear witness to the journey of the learners, to honour and celebrate their journey.

As an educator, this means that I must be willing to make myself vulnerable, that I am willing to take risks, and in taking risks, I am willing to fail (only so that I may learn). I must also strive for congruence. I must strive to "walk my talk" always. If I do not, learners will see into this and this creates mistrust and they will be afraid to take chances; they will resort to conventions and use the names others have constructed for the world to ensure their safety, for at a deep emotional and spiritual level they experience an incoherence, or incongruence, in the world. And while they may not be able to name the problem, they will be aware that there is a problem and this undermines the intimacy-always constructed in the context of honesty-that is required for true learning and knowledge construction to take place. It requires that I honour my integrity, that I always speak my truth, and that my truth is always embodied in appropriate action. And while it is hard to argue against a spiritually inspired practice, it is challenging because the dominant culture does not support this perspective on education, learning, and knowledge. To date, the dominant paradigm of education remains what Freire (1970) called the "banking approach" to education, whereby the experts "pour" the appropriate information into the empty vessels known as students, people I prefer to call learners, and in doing so squash the human spirit. And although we may no longer believe in "pouring information" into learners, more contemporary practices_-while being so-called learner- 
centred or transactional under the influence of the competency-based educational movement-still seek to move learners toward predetermined outcomes. We need to create spaces in which learner experience can be used in meaningful ways, not merely as an adjunct to the "main" learning, and there is sufficient fluidity to allow for undetermined learning outcomes. This is the learning of spirit, arising from learners creating meaning, constructing knowledge, and developing platforms of shared understanding for social and political action.

As we embrace a spirited adult education, we need to learn to find comfort, or at least some comfort, in complexity, ambiguity, and paradox (Lauzon, 1998b). We need to recognize that the rational mind seeks to resolve ambiguity and paradox, although what is called for sometimes is simply to dwell within it. We need to work at individually and collectively transcending the rational logic mind. An integral spirituality, or in Bussey's (2002) terms, a radical spirituality, requires that we embrace a new way of knowing the world and a new way of being-in-the-world. As adult educators, we cannot ignore these shifts, for our collective future may very well depend upon them.

\section{CONCLUSION}

A spiritually inspired education is an emergent education, characterized by uncertainty, ambiguity, and paradox, and is indicative of more fundamental changes that are currently taking place across the globe. Our interest in spirituality and our commitment to a spiritual educational practice are outgrowths, I believe, of the evolution of human consciousness. This requires we promote agency, while creating respectful spaces for dialogue across difference, as we aspire to develop and construct common understandings that serve as platforms for action. We must strive to remember that all true spiritual paths lead to that which unites us in our humanity. To borrow a phrase from Buber (1970), we must, as teachers, embrace learners as "thou" in relationship to our " $\mathrm{I}$ " and the " $\mathrm{I}$ " of others; there is no room in a spiritually inspired pedagogy for "its." It is in the relationship of I-thou that we recognize within one another our humanity and that we reflect back to one another our own image that connects us in our aspirations and desire for a meaningful, and authentic, existence. It is here, in this educational space, where we recognize the interrelationship of all and how an integrated understanding necessitates social justice. Spirit and justice are but the opposite sides of the same coin. A spiritually inspired pedagogy not only fosters a new way of being-in-the-world but offers us hope that as we name the world for ourselves and enter into relationship with others, we can transform the world so that all may flourish spiritually and, in doing so, develop meaningful and authentic lives for both self and others that respect others 
and the larger environment. A meaningful and authentic existence, in other words, the spiritual life, has the potential to open us up to living a compassionate and loving life, and through compassion and love we can begin to heal the fragmented existence bequeathed to us through modernity.

\section{REFERENCES}

Bateson, G. (1979). Mind and nature: A necessary unity. New York: Dutton.

Benjamin, P., \& Looby, J. (1998). Defining the nature of spirituality in the context of Maslow's and Rogers' theories. Counseling and Values, 42(2), 92-100.

Berry, T. (1988). The dream of the earth. San Francisco, CA: Sierra Club Books.

Buber, M. (1970). I and thou. New York: Charles Scribner's Sons.

Bussey, M. (2002). From change to progress: Critical spirituality and the futures of futures studies. Futures, 34, 303-315.

Castells, M. (2000). The rise of the network society ( $2^{\text {nd }}$ ed.). Oxford, UK: Blackwell Publishing.

English, L. (2003). Reclaiming our roots: Spirituality as an integral part of adult learning. Adult Learning, 12(3), 2-3.

English, L. (2005a). Spirituality. In L. English (Ed.), International encyclopedia of adult education (pp. 603-605). New York: Palgrave MacMillan.

English, L. (2005b). Historical and contemporary explorations of the social change and spiritual directions of adult education. Teachers College Record, 107(6), 1169-1192.

Freire, P. (1970). The pedagogy of the oppressed. Harmondsworth, UK: Penguin.

Hobsbawm, E. (1995). Age of extremes: The short twentieth century 1914-1991. London, UK: Abacus.

Lauzon, A. C. (1995). Exploring the foundations of an adult education for sustainable development: The unfolding story continues. Unpublished doctoral dissertation, University of Toronto, Toronto, Ontario, Canada.

Lauzon, A. C. (1998a). Adult education and the human journey: An evolutionary perspective. International Journal of Lifelong Education, 17(2), 131-145. 
Lauzon, A. C. (1998b). In search of the future: Adult education and the psychology of the soul. International Journal of Lifelong Education, 17(5), 318-327.

Lauzon, A. C. (2003). The challenges of spirituality in the everyday practices of the adult educator. Adult Learning, 12(3), 4-6.

Maher, M., \& Hunt, T. (1993). Spirituality reconsidered. Counseling and Values, $38,21-28$.

Maslow, A. (1964). Religions, values and peak-experiences. Columbus, OH: Ohio State Press.

Myers, E. (1990). Wellness through the lifespan. Guidepost, 11.

Reason, P. (1998). A participatory worldview. Resurgence, 168, 42-44.

Selman, G., \& Dampier, P. (1991). The foundations of adult education in Canada. Toronto, ON: Thompson Educational Publishing.

Spretnak, C. (1991). States of grace: The recovery of meaning in the postmodern age. San Francisco, CA: HarperSanFrancisco.

Tisdell, E. (2000). Spirituality and emancipatory adult education in women: Adult educators for social change. Adult Education Quarterly, 50(4), 308-335.

Welton, M. (2001). Little Mosie from the Margaree: A biography of Moses Michael Coady. Toronto, ON: Thompson Educational Publishing.

Wilbur, K. (1995). Sex ecology spirituality: The spirit of evolution. Boston, MA: Shambhala Publications. 


\section{BIOGRAPHY}

$\mathrm{Al}$ Lauzon is an associate professor in the School of Environmental Design and Rural Development at the University of Guelph. He teaches capacity development and qualitative analysis. His interests include the foundations of adult education, extension, and capacity development, with a specific focus on the rural Canadian context.

Al Lauzon est professeur agrégé au School of Environmental Design and Rural Development (École d'aménagement du cadre de vie et de développement rural) à l'Université de Guelph. Il enseigne le développement des capacités et l'analyse qualitative. Ses intérêts comprennent les fondements de l'éducation des adultes, la formation permanente, et le développement des capacités avec une attention particulière au contexte rural canadien. 